\title{
TECHNIQUES AND TACTICS IN BASKETBALL ACCORDING TO THE INTENSITY IN OFFICIAL MATCHES
}

\author{
TÉCNICAS E TÁTICAS DO BASQUETEBOL SEGUNDO SUA INTENSIDADE EM PARTIDAS OFICIAIS
}

TÉCNICAS YTÁCTICAS DEL BALONCESTO SEGÚN SU INTENSIDAD EN PARTIDOS OFICIALES

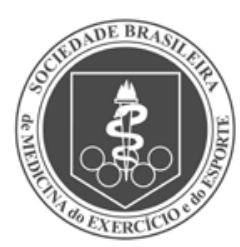

Original Article

Artigo Original

Artículo Original

\begin{abstract}
José Francisco Daniel ${ }^{1}$
(Profissional de Educação Física)

Paulo Cesar Montagner ${ }^{2}$

(Profissional de Educação Física)

Carlos Roberto Padovani ${ }^{3}$

(Estatístico)

João Paulo Borin ${ }^{4}$

(Profissional de Educação Física)

1. Pontifícia Universidade Católica de Campinas (PUC-Campinas), Faculdade de Educação Física, Campinas, SP, Brazil.

2. Universidade Estadual de Campinas (UNICAMP), Faculdade de Educação Física, Campinas, SP, Brazil.

3. Universidade Estadual Paulista (UNESP), Instituto de Biociências, Departamento de Bioestatística, Botucatu, SP, Brazil.

4. Universidade Estadual de Campinas (UNICAMP), Faculdade de Educação Física, Campinas, SP, Brazil.
\end{abstract}

\section{Correspondência:}

Pontifícia Universidade Católica de Campinas (PUC-Campinas), Rodovia Dom Pedro I, Km 136, s/n - Parque das Universidades, Campinas, SP, Brazil. 13086-900.

josefdaniel@puc-campinas.edu.br

\begin{abstract}
Introduction: Basketball is characterized as an intermittent sport in which currently stand out the highest intensity in which the actions occur, demanding for sport performance the optimum and homogeneous development of physical, technical, tactical, psychological and intellectual components. In this sense, the understanding of the game according to the technical and tactical actions performed and the knowledge of body's responses are important for planning, monitoring and control of the training. Objective: The aim of this study was to describe the intensity of basketball tactical actions and the relationships between technical actions and intensity during the different game periods (GP). Methods: Ten athletes of the Brazilian male basketball elite participated in this study $(27.60 \pm 5.54$ years, $192.62 \pm 7.63 \mathrm{~cm}, 91.60 \pm 11.51 \mathrm{~kg}, 10.66 \pm 4.11 \%$ of body fat) in six official matches of the National Basketball League (LNB, Brazil). Anthropometric measures and motor tests were performed and tactical (defensive, offensive and transition), technical [shares number (SN) and efficiency ratio (ER)] and physical actions [percentage of lactate threshold heart rate $\left.\left(\% H R_{\text {thr }}\right)\right]$ were correlated. Spearman's correlation coefficient was used between SN, ER and \%HR thr. Results: The main results point to: (1) positive and significant relationship (except the $4^{\text {th }} \mathrm{GP}$ ) between $\mathrm{SN}$, ER and \%HR thri $^{\text {(2) }}$ ) tactical actions presented HR near the lactate threshold, being apparently the highest median for the transitions $\left(107.4 \% H R_{\text {thr }}\right)$. Conclusion: The game is intense, with moments of $\mathrm{HR}_{\text {peak }}$, but the median is slightly above of $\mathrm{HR}_{\mathrm{thr}}$ that it is where the best relationship between $\mathrm{SN}$ and ER occurs.
\end{abstract}

Keywords: athletes; athletic performance; basketball.

\section{RESUMO}

Introdução: O basquetebol é caracterizado como um esporte intermitente, no qual, atualmente se destaca a maior intensidade com que as ações ocorrem, exigindo para o desempenho esportivo o desenvolvimento ótimo e homogêneo dos componentes físico, técnico, tático, psicológico e intelectual. Neste sentido, o entendimento do jogo de acordo com as ações técnicas e táticas e o conhecimento das respostas do organismo são importantes para planejamento, monitoramento e controle do treinamento. Objetivo: O objetivo deste estudo foi descrever a intensidade das ações táticas do basquetebol e as relações entre as ações técnicas e a intensidade ao longo dos diferentes períodos do jogo (PJ). Métodos: Participaram deste estudo 10 atletas da elite do basquetebol masculino brasileiro $(27,60 \pm 5,54$ anos, $192,62 \pm 7,63 \mathrm{~cm}, 91,60 \pm 11,51 \mathrm{~kg}, 10,66 \pm 4,11 \%$ de gordura) em seis partidas da Liga Nacional de Basquetebol (LNB). Foram realizados medidas antropométricas e testes motores e foram correlacionadas as ações táticas (defensiva, ofensiva e de transição), técnicas (número de participações [NP] e indice de eficiência [IE]) e físicas (percentual da frequência cardíaca de limiar de lactato [\% FC lim]). O coeficiente de correlação de Spearman foi usado entre NP, IE e \%FC lim. Resultados: Os principais resultados apontam para: (1) relação positiva e significativa (exceto o 40 PJ) entre NP, IE e \%FC lime (2) as ações táticas apresentaram FC próximas do limiar de lactato, sendo aparentemente a maior mediana para as transições $\left(107,4 \% F C_{\text {lim }}\right.$ ). Conclusão: O jogo é intenso, com momentos de $F C_{\text {pica }}$ mas a mediana está ligeiramente acima da $F C_{\text {lim’ }}$ faixa em que ocorre a melhor relação entre NP eIE.

Descritores: atletas; desempenho atlético; basquetebol.

\section{RESUMEN}

Introducción: El baloncesto se caracteriza como un deporte intermitente, en el cual actualmente se destaca la mayor intensidad con que ocurren las acciones, exigiendo para el rendimiento deportivo el desarrollo óptimo y homogéneo de los componentes físico, técnico, táctico, psicológico e intelectual. En este sentido, el entendimiento del juego de acuerdo con las acciones técnicas y tácticas y el conocimiento de las respuestas del organismo son importantes para el planeamiento, monitoreo y control del entrenamiento. Objetivo: El objetivo del presente estudio fue describir la intensidad de las acciones tácticas del baloncesto y las relaciones entre las acciones técnicas y la intensidad a lo largo de los distintos periodos del juego (PJ). Métodos: En este estudio participaron 10 atletas de la elite del baloncesto masculino brasileño $(27,60 \pm 5,54$ años, $192,62 \pm 7,63 \mathrm{~cm}, 91,60 \pm 11,51 \mathrm{~kg}, 10,66 \pm 4,11 \% \mathrm{de}$ grasa) en seis partidos de la Liga Nacional de Baloncesto (LNB, Brasil). Se realizaron medidas antropométricas y pruebas motoras y se correlacionaron acciones tácticas (defensiva, ofensiva y de transición), técnicas (número de participaciones [NP] y el índice de eficiencia [IE]) y físicas (porcentaje de la frecuencia cardiaca de umbral de lactato 
[\%FC U]]). El coeficiente de correlación de Spearman fue utilizado entre NP, IE y \%FC UL. Resultados: Los principales resultados muestran (1) relación positiva y significativa (excepción el 40 PJ) entre NP, IE y \%FC UL (2) las acciones tácticas mostraron FC cerca del umbral de lactato, siendo aparentemente la mayor mediana para las transiciones (107,4\% FC $C_{U L}$ ). Conclusión: A partir de los resultados, se concluye que el juego de baloncesto es intenso, con momentos en que la $F C_{\text {picc }}$ es alcanzada, pero con mediana ligeramente superior a la $F C_{U U^{\prime}}$, período en que ocurre la mejor relación entre NP e IE.

Descriptores: atletas; rendimiento atlético; baloncesto.

\section{INTRODUCTION}

The knowledge on the physical, techniques and tactics demands of a sport is crucial for teams to achieve their goals, because the entire training process should be based on the reality of the competition?.

Specifically in relation to basketball, the physical demand of the matches had a considerably increase after the changes in the rules that occurred in the $2000 \mathrm{~s}^{2}$. It seems that such changes have occurred because of the specific needs of the matches, with defensive, offensive and transition tactics, in which players use techniques and tactics actions for the solution of tasks ${ }^{3-5}$.

In the adult male category, the few studies performed during official matches have shown the percentages of maximum heart rate (HR) according to the duration and frequency of the moments of live and stoppage times ${ }^{6}$, or have analyzed indicators of technical actions and intensity according to the players positions ${ }^{5}$. Different values of HR have been obtained by other authors in official matches, that analyzed under-19 category ${ }^{7}$, women's basketball ${ }^{8}$ or athletes in friendly matches ${ }^{9,10}$. Two studies worked with lactate threshold $H R\left(H R_{\text {thr }}\right)$. One of them associated with technical actions ${ }^{5}$ and other, determined previously, but without analysis of matches ${ }^{8}$. According to Ziv and Lidor ${ }^{11}$, the lactate threshold is an indicator of aerobic capacity that allows the realization of intermittent intense actions, with a relatively brief pause and the consequent maintenance of an intense pace in the basketball match, and studies are needed under this view.

On the other hand, it must be highlighted that the HR is responsive to the actions carried out and that they occur in match, according to tactics and techniques needs. In this sense, the HR responses must be analyzed according to the tactics and techniques actions. We have found only the study of Ben Abdelkrim et al. ${ }^{12}$ who presented the HR of under-19 players in official matches, depending on the prevailing tactic defensive system and the technical level of the players and the study of Daniel et al. ${ }^{5}$ on the intensity of technical actions according to the players' positions. It must be highlighted the importance of know the HR of the defensive, offensive and transition actions.

Moreover, the analysis of the technique and tactic performance in matches are made through stats of game indicators ${ }^{13}$, with few studies associated with the physical requirements ${ }^{5,12}$.

Techniques and tactics actions in a basketball match happen unpredictably and variably, with specific physical demands, depending on the action and momentum of the match. Therefore, there may be some relationship between the intensity, represented by the $H R$, the frequency of techniques ${ }^{5}$ and tactics actions in match ${ }^{12}$ and the efficiency of these actions. However, despite the relevant studies, there seems to be a gap in this sense and in relation to the analysis of the $H R_{\text {thr }}$ in adult male category.

In this way, the aims of this study were to describe the intensity of basketball tactical actions and the relationships between technical actions and the intensity over the different match periods.

\section{MATERIALS AND METHODS}

Ten elite basketball male players, from one team, were observed in six official matches, in the first round of qualifying phase of Brazilian Basketball League.

For inclusion in the study, the players underwent clinical and laboratory assessment with the team doctor before the beginning of the activities. All subjects were informed about the study and signed a consent form approved by the Research Ethics Committee of the University of Campinas (UNICAMP) (protocol 1008/2010).

Initially, anthropometric assessment were performed for the team characterization and motor testes to determine peak heart rate $\left(H R_{\text {peak }}\right)$ (Repeat Sprints Test - RST ${ }^{14}$ ) and threshold heart rate $\left(H R_{\text {thr }}\right)$ (Intermittent Shuttle-Running Test - ISRT ${ }^{15}$ ). Percentage of body fat was determined using Lange Skinfold Caliper adipometer (Beta Technology Incorporated, Cambridge, Maryland, USA); body density was estimated by measurement of seven skinfolds ${ }^{16}$ and percent body fat by using Siri method (1956)

HR was determined using ten HR transmitters of the Polar ${ }^{\oplus}$ brand (Team System model, Finland). It was considered as $H_{\text {peak }}$ the highest HR presented between RST ${ }^{14}$ and the analyzed matches. RST $^{14}$ consisted of 10 shuttle-run sprints of $15+15 \mathrm{~m}$, interspersed by 30 seconds of passive recovery; and ISRT ${ }^{15}$ consisted of 4 minutes of 20 m shuttle-running at 9 , 10 and $11 \mathrm{~km}-\mathrm{h}^{-1}$ interspersed with 1 minute of passive rest; blood-lactate concentrations [lac] were assessed at passive rest, after each one of the three speeds; lactate threshold speed was considered by the increase of $1 \mathrm{mmol}-\mathrm{L}^{-1}$ [lac] in relation to rest levels; the HR obtained at the end of the 4 minutes of the threshold speed was considered the $\mathrm{HR}_{\text {thri }} \% \mathrm{HR}_{\text {thr }}$ was calculated by the ratio between $H R_{\text {thr }}$ and $H R_{\text {peak }}$.

For familiarization with the HR transmitters, the athletes participated of six training sessions with simulated matches and then in six official matches, In matches' days, the transmitters were placed on chest of players and synchronized with time of a digital timer, Casio ${ }^{\circledR}$ brand, before heading to the warm up in court. Table 1 shows athletes' anthropometric and performance indicators.

The collections of tactics and techniques components were made by notes and video analysis of matches. For the video record it was used a camcorder, JVC ${ }^{\circledR}$ brand (HD Everio GZ-HM690 model, Malaysia), positioned in middle of stands, in last flight of steps.

Table 1. Anthropometric and performance indicators.

\begin{tabular}{|c|c|c|c|}
\hline Variable & $\begin{array}{c}\text { All subjects } \\
(n=10)\end{array}$ & Maximum & Minimum \\
\hline Age (years) & $27.6 \pm 5.54$ & 40.0 & 21.0 \\
\hline Height $(\mathrm{cm})$ & $1.9 \pm 0.1$ & 2.0 & 1.8 \\
\hline Body weight (kg) & $91.6 \pm 11.5$ & 107.8 & 72.4 \\
\hline Percent body fat (\%) & $10.7 \pm 4.1$ & 18.6 & 5.1 \\
\hline $\mathrm{HR}_{\text {thr }}$ (beats/min) & $164.5 \pm 4.2$ & 170.0 & 157.0 \\
\hline$H R_{\text {peak }}$ (beats/min) & $189.7 \pm 9.5$ & 199.0 & 168.0 \\
\hline Percent $H R_{\text {thr }}$ from $H R_{\text {peak }}(\%)$ & $86.7 \pm 3.2$ & 93.5 & 83.9 \\
\hline
\end{tabular}


According to time of a progressive timer, a researcher registered the start and end times of the periods, the players on the court, time outs, interruptions and occurrences that were beyond the normality of the match.

The tactical component was analyzed by the $\% \mathrm{HR}_{\text {thr }}$ according to the actions of defense (beginning with a defensive and organized numerical balance of the five players), offense (beginning when the opposing defense is positioned and organized in its system with the five players), defense transition (beginning when the team loses the ball possession and ending when the defense is positioned with its five players and there is the numerical and organized balance) and offense transition (beginning at the recovery of ball possession and ending when the opposing defense is positioned with its five players and there is the organized and numerical defense balance $)^{4}$.

The notes were made by video analysis adopting the following procedures: at the beginning of each match period it was started a progressive stopwatch, which was stopped at the end of period. Whenever there was a change of tactic action, it was noted the time appointed by the stopwatch and the corresponding action. Regarding the technical component, it was used the association between the total frequency of match indicators (SN) and efficiency ratio (ER), using official stats from match (free throws, field goals, offensive and defensive rebounds, assists, steals, blocks, turnovers and fouls). The SN corresponds to the sum of all match indicators of each athlete included in the stats. The ER was obtained by consulting the match stats, which uses the following formula: (points + rebounds + blocks + steals + assists) - (field goals missed + free throws missed + turnovers).

After collection and organization of the data, the descriptive measures of the $\% H R_{\text {thr }}$ according to the tactical components (defense, offense, defense transition and offense transition), match period (MP) and the entire match, and the technical components (SN and ER), according to the MP were calculated. Spearman's correlation coefficient was used to verify the association between $\mathrm{SN}, \mathrm{ER}$ and $\% \mathrm{HR}_{\mathrm{thr}}$ and they were considered as statistically significant when $\mathrm{p} \leq 0.05$. The data were processed with the software SPSS 16.0 (Statistical Package for the Social Sciences, Inc., Chicago, IL, USA).

\section{RESULTS}

The $\% \mathrm{HR}_{\text {thr }}$ of tactic action according to the MP were close in the entire match, however, it was observed an apparently reduction in the values throughout the MP (Table 2).

The $\% \mathrm{HR}_{\text {thr, }}$ SN and ER were separated by MP. It was found a positive and significant relationship between $\% \mathrm{HR}_{\text {thr }}$ SN and ER, except for the $4^{\text {th }} \mathrm{MP}$. From the $1^{\text {st }} \mathrm{MP}$ to the $4^{\text {th }} \mathrm{MP}$ the $\% \mathrm{HR}$ thr apparently decreased, but SN (4.3, 3.9, 4.3 and 4.2) and ER (2.2, 2.0, 2.4 and 1.8) showed another pattern (Table 3).

Table 2. Median of lactate threshold heart rate percentage $\left(\% H R_{\text {thr }}\right)$ of tactical actions according to match periods (MP) and entire match (EM).

\begin{tabular}{c|c|c|c|c|c}
\hline & $\mathbf{1}^{\text {st }} \mathbf{M P}$ & $\mathbf{2}^{\text {nd }} \mathbf{M P}$ & $\mathbf{3}^{\text {th }} \mathbf{M P}$ & $\mathbf{4}^{\text {th }} \mathbf{M P}$ & $\mathbf{E M}$ \\
\hline Defense & 106.8 & 104.1 & 102.5 & 101.8 & 104.2 \\
\hline Offense & 105.6 & 103.5 & 103.1 & 101.2 & 103.7 \\
\hline Defense Transition & 107.4 & 101.8 & 103.7 & 102.8 & 104.8 \\
\hline Offense Transition & 107.4 & 105.5 & 102.1 & 99.4 & 104.3 \\
\hline
\end{tabular}

Table 3. Linear association frequency of share number (SN), efficiency ratio (ER), and heart rate lactate threshold percentage (\%HR $\left.\mathrm{Hhr}_{\mathrm{thr}}\right)$ according to match periods (MP).

\begin{tabular}{c|c|c|c|c}
\hline Associação & $\mathbf{1}^{\text {st }} \mathbf{M P}$ & $\mathbf{2}^{\text {nd }} \mathbf{M P}$ & $\mathbf{3}^{\text {th }} \mathbf{M P}$ & $\mathbf{4}^{\text {th }} \mathbf{M P}$ \\
\hline SN vs ER & $0.763 p<0.001$ & $0.763 p<0.001$ & $0.686 p<0.001$ & $0.639 p<0.001$ \\
\hline SN vs \%HR $\mathrm{thh}_{\text {thr }}$ & $0.577 p<0.001$ & $0.670 p<0.001$ & $0.376 p<0.01$ & $0.316 p<0.05$ \\
\hline ER vs \%HR thr & $0.375 p<0.01$ & $0.496 p<0.001$ & $0.319 p<0.05$ & $0.277 p>0.05$ \\
\hline
\end{tabular}

\section{DISCUSSION}

The presentation of the intensity of basketball tactics actions and the relationships between technical actions and the intensity over the different match periods are important in the context of sports training. In this sense, this study points to relevant issues to be discussed. The main results point to: (1) positive and significant relationship between $\% \mathrm{HR}_{\text {thr }}$ SN and ER, except for $4^{\text {th }} \mathrm{MP}$; (2) the tactics actions presented HR close to the $H R_{\text {thr }}$, but between MP the offense transition stood out in the first two and the defense transition in the last two.

As this study was done in a real competition situation, in six official matches of LNB, the main Brazilian basketball competition and the athletes participation depended on the technical commission decisions, the players had different time of performance in the MP and matches, or until did not play in some MP and or matches. In this case, it became impracticable to use statistical tests to compare the intensity of tactical actions.

Regarding the techniques actions, some authors ${ }^{13,17}$ have showed that the success of teams is associated with the highest volume of some indicators, e.g., rebounds, assists, steals and blocks, as well as greater success in the field goals. In this study, it was found that there is positive association between $\mathrm{SN}, \mathrm{ER}$ and $\% \mathrm{HR}_{\text {thr }}$.

The highest associations between SN vs ER occurred in the $1^{\text {st } M P}$ and $2^{\text {nd }} M P(r=0.763)$, while between SN vs $\% \mathrm{HR}_{\text {thr }}(r=0.670)$, and ER vs $\% \mathrm{HR}_{\text {thr }}(r=0.496)$ the highest associations were observed in the $2^{\text {nd }} M P$.

The highest match intensity was verified in the $1^{\text {st }} \mathrm{MP}$, which may have provided momentary fatigue and, consequently, worse choices related to techniques and tactics actions, resulting in more errors and less ER. In this way, it has been reported that motor fatigue impairs both cognition and motor precision ${ }^{18}$, being inversely proportional to blood lactate concentration ${ }^{19}$.

In the $4^{\text {th }} \mathrm{MP}$, apparently it was observed a lower strength of association and the lowest intensity. In fact, the $4^{\text {th }} \mathrm{MP}$ is marked by the performance of the lowest number of intense actions ${ }^{7}$ and the shortest duration of the times when the ball is in play (live ball) ${ }^{20}$, but there is a need for further studies in this regard.

In relation to the tactics actions according to intensity, Ben AbdeIkrim et al. ${ }^{12}$ have presented the HR of man-to-man defensive actions $\left(93.3 \% \pm 2.1 \% H R_{\max }\right)$ and zone marking $\left(92.3 \pm 2.3 \% H R_{\max }\right)$, in the under-19 male category. In our study, the differences between the averages of the $\mathrm{HR}$ in the tactics actions were less than $1 \%$ and close to the $\% H R_{\text {thr. }}$

Basketball is a complex game, with intermittent, unpredictable and variable actions ${ }^{3}$ performed at various intensities. The most intense actions occur every 21 seconds, approximately ${ }^{21}$ the intensities of activity and movement patterns during men's basketball were investigated by videoing the movements and monitoring the heart rate and blood lactate responses of eight elite players during competition. The results are expressed according to 'live time', which is actual playing time, and 'total time', which includes live time as well as all stoppages in play. The mean (+/- S.D., regardless of the performed tactic (defense, offense, defense transition and offense transition). Among the most intense actions there are others and this combination may result in more or less fatigue, evidenced by the values of HR. In this way, it has been verified that under-19 basketball players, of international level, have higher values of HR in matches and act in more intense actions than national level players. On the other hand, they also remain longer in the low intensity zone ${ }^{12}$. In this sense, there is an optimal relationship in the combination of actions, in which the average can be found near the lactate threshold. This can be justified by the fact that blood lactate concentration is related to cognitive and motor mistakes ${ }^{19}$; therefore, must have enough recovery time between actions. 
When the HR was analyzed according to the tactics actions and MP, it was observed that the match moments presented specific characteristics, which point to the priorities or objectives of the team in each MP. Apparently, in the $1^{\text {st }} \mathrm{MP}$ and $2^{\text {nd }} \mathrm{MP}$, the highest values of HR were presented in the transitions. In the $1^{\text {st }} \mathrm{MP}$ for both, in the $2^{\text {nd }} \mathrm{MP}$ for offense transition and in the $3^{\text {rd }} \mathrm{MP}$ and $4^{\text {th }} \mathrm{MP}$ in the defense transition (Table 1). In the $1^{\text {st } M P}$ of match the teams seek to impose their pace, with strong defense and defense transition to suffer fewer points and with offense transition, which is one of the most discriminating factors in wins ${ }^{22}$. As the match progresses and more specifically in the $4^{\text {th }} \mathrm{MP}$ the teams seek to manage differently the actions of the match, including longer timeouts ${ }^{7}$, and ensure the quick defense transition.

It was also verified a decrease in values of \%HR over the MP, which is consistent with the results presented by Borin et al. ${ }^{23}$ in different match periods (MPs, with basketball referees who worked in the same competition, but in another season. The decrease in the \%HR over the MP can be justified, in part, by the characteristic of the match progress. For example, Borin et al. ${ }^{20}$ found that the moments of live time in $4^{\text {th }} \mathrm{MP}$ are less durable and more frequent than in the other MP, and Ben Abdelkrim et al. ${ }^{7}$ also shows that the duration of moments of stoppage time is greater and therefore the HR is lower.
The physical requirements of basketball are derived from technical and tactical actions, which in turn depend on the momentary needs of the matches. This is an open field for studies for both genders, in the various age groups and competition phases.

\section{CONCLUSIONS}

The knowledge that the SN, ER and \%HR thr have positive association points to the match volume, which must be enough in relation to the characteristics of the opponent. The issue that association is situated near the $H R_{\text {thr }}$ indicates that pace of the match should be optimal in relation to the combination of intensity with moments of recovery, so that the median among them is near the lactate threshold. The match is developed at a faster pace for all tactics actions, but with some highlights according to the needs or objectives of team. All tactics actions must be trained at optimal intensity, but respecting the balance between play and rest, or intense, moderate or light actions.

All authors declare no potential conflict of interest related to this article.

AUTHORS' CONTRIBUTIONS: Each author made significant individual contributions to this manuscript. JPB (0000-0002-7393-4053)* e PCM (0000-0002-5764-8022* contributed substantially to the conception and design of the study, staff coordination, and critical revision of the manuscript for important intellectual content and final approval of the version to be published. JFD (0000-0001-8148-581X)* were responsible for data acquisition. JFD (0000-0001-8148-581X)* and JPB (0000-0002-7393-4053)* were responsible for writing of the manuscript. CRP (0000-0002-7719-9682)* provided statistical and scientific input and critical revision of the manuscript. * ORCID (Open Researcher and Contributor ID).

\section{REFERENCES}

1. Platonov V. Teoria geral do treinamento desportivo olímpico. Porto Alegre: Artmed; 2004

2. Cormery B, Marcil M, Bouvard M. Rule change incidence on physiological characteristics of elite basketball players: a 10-year- period investigation. Br J Sports Med. 2008;42(1):25-30.

3. Jordane F, Martin J. Baloncesto bases para el alto rendimiento. Barcelona: Hispano Europea; 1999.

4. Paes RR, Montagner PC, Ferreira HB. Pedagoria do esporte iniciação e treinamento em basquetebol. Rio de Janeiro: Koogan; 2009.

5. Daniel JF, Montagner PC, Padovani CR, Borin JP. Indicadores de ações técnicas e de intensidade de acordo com as posições dos jogadores em partidas oficiais da liga brasileira de basquetebol. E-Balonmano.com Rev Ciencias del Deport. 2016;12(2):89-96. http://www.e-balonmano.com/ojs/index.php/revista/article/ viewFile/352/332. [acesso em 2016 dez 21]

6. Daniel JF, Bonganha V, Mercadante LA, Cavaglieri CR, Montagner PC, Borin JP. Basketball: long live time duration require higher loads on heart rate, but they are less frequently. In: Balagué $N$, Torrents $C$ Vilanova A, Cadefau J, Tarragó R, Tsolakidis E, editors. 18th Annual Congress of the European College of Sport Science. Barcelona; 2013. p. 683-684.

7. Ben Abdelkrim N, El Fazaa S, El Ati J. Time-motion analysis and physiological data of elite under-19-year-old basketball players during competition. Br J Sports Med. 2007;41(2):69-75.

8. Rodríguez-Alonso M, Fernández-García B, Pérez-Landaluce J, Terrados N. Blood lactate and heart rate during national and international women's basketball. J Sports Med Phys Fitness. 2003;43(4):432-6.

9. Vaquera $\mathrm{A}$, Refoyo I, Villa JG, et al. Heart rate response to game-play in proessional basketball players. $J$ Hum Sport Exerc. 2008;3(1):1-9. http://rua.ua.es/dspace/handle/10045/3675. [acesso em 2015 mai 23]

10. Torres-Ronda L, Ric A, Llabres-Torres I, de las Heras B, Schelling i del Alcazar X. Position-Dependent Cardiovascular Response and Time-Motion Analysis During Training Drills and Friendly Matches in Elite Male Basketball Players. J Strength Cond Res. 2016;30(1):60-70.

11. Ziv G, Lidor R. Physical attributes, physiological characteristics, on-court performances and nutritional strategies of female and male basketball players. Sport Med. 2009;39(7):547-68.
12. Ben Abdelkrim N, Castagna C, El Fazaa S, El Ati J. The effect of players'standard and tactical strategy on game demands in men's basketball. J Strength Cond Res. 2010;24(10):2652-62.

13. Ibáñez SJ, Sampaio J, Feu S, Lorenzo A, Gómez MA, Ortega E. Basketball game-related statistics that discriminate between teams'season-long success. Eur J Sport Sci. 2008;8(6):369-372.

14. Castagna C, Manzi V, D'Ottavio S, Annino G, Padua E, Bishop D. Relation between maximal aerobic power and the ability to repeat sprints in young basketball players. J Strength Cond Res. 2007;21 (4):1172-6.

15. Castagna C, Manzi V, Impellizzeri F, Chaouachi A, Ben Abdelkrim N, et al. Validity of an on-court lactate threshold test in young basketball players. J Strength Cond Res. 2010;(16):2434-39.

16. Jackson AS, Pollock ML. Generalized equations for predicting body density of women. Br J Nutr. 1978;40:497-504.

17. Sampaio J, Drinkwater EJ, Leite NM. Effects of season period, team quality, and playing time on basketball players' game-related statistics. Eur J Sport Sci. 2010;10(2):141-9.

18. Lorist MM, Kernell D, Meijman TF, Zijdewind I. Motor fatigue and cognitive task performance in humans. J Physiol. 2002;545(Pt 1):313-9.

19. Coco M, Di Corrado D, Calogero RA, PerciavalleV, Maci T, PerciavalleV. Attentional processes and blood lactate levels. Brain Res. 2009;1302:205-11.

20. Borin JP, Gonçalves A, Padovani CR, Aragon FF. Perfil da intensidade de esforço nas ações e nos tempos do jogo de basquete de alto nível. Salusvita. 2005;24(3):411-8.

21. McInnes SE, Carlson JS, Jones CJ, McKenna MJ. The physiological load imposed on basketball players during competition. J Sports Sci. 1995;13(5):387-397.

22. Šeparović $\vee$, Nuhanović A. Nonstandard indicators of the offensive effectiveness in basketball. Sport Sci. 2008;1:7-11.

23. Borin JP, Daniel JF, Bonganha V, Moraes AM, Cavaglier CR, Mercadante LA. The distances covered by basketball referees in a match increase throughout the competition phases, with no change in physiological demand. Open access J Sport Med. 2013;4:193-8. 